The greatly increased risk of secondary leukaemia in patients treated with the nitrosourea lomustine is the major new finding in the present study. Lomustine (CCNU) is known to be leukaemogenic in other cancers $^{24}$ and was identified as a risk factor in Hodgkin's disease in a smaller case-control study by Nayfield and Cuzick. ${ }^{1+}$ In our series, however, most patients who developed leukaemia had received this drug $(9 / 17$, $53 \%$ ), and despite the fact that it is used as second or third line treatment in relapsed patients the risk due to lomustine seemed to be independent of treatment quantity. No significant difference was observed when lomustine was given as maintenance treatment compared with its more usual role as a salvage drug, but the number of patients maintained on the drug was too small to allow meaningful conclusions to be drawn.

The reason for the special risk associated with treatment with lomustine is not clear, but it may be related to the way in which the drug is used: it is usually given as chronic low dose treatment to relapsed patients who have already received a considerable amount of other treatment. It is of interest that another study found a high risk of leukaemia in patients given chronic low dose chlorambucil as maintenance treatment. ${ }^{11}$ Whatever the reason for the particular leukaemogenicity of lomustine in our study, the finding is of interest because of the increasing use of nitrosoureas in high dose salvage regimens. No cases of leukaemia have yet Eeen observed in patients treated in this way in the British National Lymphoma Investigation's studies, but numbers are still small and follow up short.

There are two major implications of this study. Firstly, concern over the occurrence of secondary leukaemia when radiotherapy and chemotherapy are combined is misplaced. Secondly, it is clear that most cases of leukaemia occur in heavily treated patients with multiple relapses of Hodgkin's disease, few of whom would be expected to be cured of their Hodgkin's disease; indeed, many had active lymphoma when their leukaemias were diagnosed. Control of Hodgkin's disease remains the main problem, and there is thus no sound basis for reducing the intensity of treatment to avoid secondary leukaemias. The risks of other second malignancies may be a more serious concern and careful analysis of their occurrence is in progress.

We thank all the participants in the British National Lymphoma Investigation who contributed information and the staff of the investigation's secretariat, particularly Ms Jan Bonner for help with data collection. Thanks also to Ms
Alison Douglas of the London School of Hygiene and Tropical Medicine for help with the multivariate analysis. Part of the study was submitted as a dissertation for an MA degree in econometrics and social statistics by TGS.

1 Lacher MJ, Susman LN. Leukaemia and Hodgkin's disease. Ann Intern Med 1963:59:369-78

2 Arseneau JC, Sponzo RW, Levin DL. Non lymphomatous malignant tumours complicating Hodgkin's disease. N Engl f Med 1972;287:1119-22.

3 Coleman CN, Williams CJ, Flint A, Glatstein EJ, Rosenberg S, Kaplan HS. Hematological neoplasia in patients treated for Hodgkin's disease. $N$ Englf Med 1977;297:1249-52

4 Aisenberg AC. Acute nonlymphocytic leukaemia after treatment of Hodgkin's disease. Am J Med 1983;75:449-53.

5 Tester WJ, Kinsella TJ, Waller B, et al. Second malignant neoplasms complicating Hodgkin's disease: the National Cancer Institute experience. f Clin Oncol 1984;2:762-9.

6 Valagussa P, Santoro A, Fossati-Bellani F, Banfi A, Bonadonna G. Second acute leukaemia and other malignancies following treatment for Hodgkin's disease. 7 Clin Oncol 1986;4:830-7.

7 Blayney DW, Longo DL, Young RC, et al. Decreasing risk of leukaemia with prolonged follow up after chemotherapy and radiotherapy for Hodgkin's prolonged follow up after chemothera

8 Tucker MA, Coleman CN, Cox RS, Varghese A, Rosenberg S. Risk of second cancers after treatment for Hodgkin's disease. N Engl f Med 1988;318: 76-81.

9 Baccarani M, Bosi A, Papa G. Second malignancy in patients treated for Hodgkin's disease. Cancer 1980;46:1735-40.

10 Coltman CA, Dixon DO. Second malignancies complicating Hodgkin's disease: a Southwest Oncology Group 10 year follow up. Cancer Treat Rep 1982;66:1023-33.

11 Glicksman AS, Pajak TF, Gottlieb A, Nissen N, Stutzman L, Cooper MR Second malignant neoplasms in patients successfully treated for Hodgkin's disease: a Cancer and Leukaemia Group B study. Cancer Treatment Reports 1982;66:1035-44.

12 Pedersen-Bjergaard J, Larsen SO. Incidence of acute nonlymphocytic leukaemia, preleukaemia and acute myeloproliferative syndrome up to 10 years after treatment of Hodgkin's disease. $N$ Engl F Med 1982;307:965-71.

$13 \mathrm{Papa} \mathrm{G}$, Mauro FR, Anselmo AP, et al. Acute leukaemia in patients treated for Hodgkin's disease. Br f Haematol 1984;58:43-52.

14 Nayfield SG, Cuzick J. Clinical predictors of acute leukaemia in patients treated for Hodgkin's disease: a case control study. Blood 1987;70 treated for

15 Kaldor JM, Day NE, Clarke A, et al. Leukaemia following Hodgkin's disease. $N$ Engl f Med 1990;322:7-13.

16 Grunwald H, Rosner F. Acute myeloid leukaemia following treatment of Hodgkin's disease. Cancer 1982;50:676-83.

17 Levine EG, Bloomfield CD. Secondary myelodysplastic syndromes and leukaemias. Semin Hematol 1986;4:1037-80.

18 Bennett JM, Catovsky D, Daniel M-T, et al (FAB Co-operative Group). Proposals for the classification of the acute leukaemias. $\mathrm{Br} \mathcal{F}$ Haematol 1976;33:451-8.

19 Bennett JM, Catovsky D, Daniel M-T, et al. Criteria for the diagnosis of acute leukaemia of megakarocytic lineage $M 7$. A report of the FAB group. Ann Intern Med 1985:103:460-2.

20 Bennett JM, Catovsky D, Daniel M-T, et al. Proposals for the classification of the myelodysplastic syndromes. Br f Haematol 1982;51:189-99.

21 Armitage P. Berry G. Statistical methods in medical research. 2nd ed. Oxford: Blackwell Scientific, 1987:428-9.

22 Bennett MH, MacLennan KA, Easterling MJ, Hudson VB, Hudson VG, Jelliffe AM. Analysis of histological sustypes in Hodgkin's disease in relation to prognosis and survival. In: Quagliono D, Hayhoe FGJ. Proceeding of the international symposium on cytobiology of leukaemias and lymphoma $1985 ; 20: 15-32$

23 Breslow NE, Day NE. The analysis of case control studies In: Statistical methods in cancer research. Vol 1. Lyons: International Agency for Research on Cancer, 1980:169-76.

24 Boice JD, Greene MH, Killen JY Jr, et al. Leukaemia and preleukaemia after adjuvant treatment of gastrointestinal cancer with semustine (methyl CCNU). $N$ Engl f Med 1983;309:1079-84.

(Accepted 8 August 1990)
Department of Medicine,

Chesterfield and North

Derbyshire Royal Hospital,

Chesterfield S44 5BL

Nigel $M$ Wheeldon, MRCP, medical registrar

Michael J Grundman, FRCP, consultant physician and gastroenterologist

Correspondence to:

Dr Grundman.

BrMed F 1990;301:1080-1

\section{Ischaemic colitis as a complication of colonoscopy}

\section{Nigel $M$ Wheeldon, Michael J Grundman}

Ischaemic colitis complicating colonoscopy is apparently rare. Indeed, a Medline search of reports published in the past 10 years found no such case.

\section{Case report}

A woman aged 59 presented in 1985 with dyspepsia and loose motions. She had had Raynaud's phenomenon since a teenager, arthralgia, and a photosensitive facial rash suggestive of systemic lupus erythematosus. Biopsy of the skin lesion had shown discoid lupus erythematosus, and she had been positive for antibodies to nuclear ( 1 in 200) and double stranded ( 1 in 160) DNA on several occasions.

Clinical examination was unremarkable, but rigid sigmoidoscopy showed a $1 \mathrm{~cm}$ polyp at $15 \mathrm{~cm}$ which histological examination identified as a tubular adenoma. This and another adenomatous polyp at $35 \mathrm{~cm}$ were removed by snare diathermy at total colonoscopy. Her abdominal symptoms settled. Follow up colonoscopy was performed after six months (one tiny metaplastic polyp removed by diathermy), one year, and three years; no evidence of recurrent polyps or other abnormality was found.

The five year colonoscopy in January 1990 was apparently not traumatic. Endoscopy lasted only 15 minutes, no procedures were undertaken, and no abnormality was seen. A few hours after colonoscopy she developed colicky lower abdominal pain, vomiting, and watery diarrhoea. After 24 hours she developed fresh, and later dark, rectal bleeding and was admitted to hospital. 
On admission she looked pale and unwell but her temperature was normal. Abdominal examination showed lower abdominal tenderness, guarding, and rebound, particularly in the left iliac fossa. She also had an epigastric bruit, but no pulsatile mass was palpable and peripheral pulses were normal.

Investigations showed a haemoglobin concentration of $141 \mathrm{~g} / \mathrm{l}$, white cell count $24 \cdot 4 \times 10^{9} / 1$ (neutrophilia), platelet count $255 \times 10^{9} / 1$, erythrocyte sedimentation rate $33 \mathrm{~mm}$ in the first hour, and sodium concentration $129 \mathrm{mmol} / \mathrm{l}$; urea and electrolyte concentrations and amylase activity were normal. Stool microscopy and culture gave negative results. An erect chest radiograph was normal, showing no free subdiaphragmatic gas, but supine abdominal radiography suggested mucosal oedema of the transverse and distal colon. Sigmoidoscopy to $12 \mathrm{~cm}$ showed severely inflamed mucosa with contact bleeding, and multiple biopsy specimens were taken, which showed patchy areas of destruction with necrotic debris heavily laden with polymorphs. Intact, fairly normal mucosa was also seen, implying focal destruction. Tests for antibodies to nuclear and double stranded DNA were negative.

Ischaemic colitis was diagnosed, and she was treated conservatively with intravenous fluids and analgesia.
Over the next three days her condition improved, although her haemoglobin concentration fell by almost $30 \mathrm{~g} / \mathrm{l}$. Because of her history of systemic lupus erythematosus and her epigastric bruit she underwent mesenteric arteriography, which showed no abnormality. On day 5 , when her condition was improving, a barium enema gave normal results, reflecting rapid mucosal recovery.

She was discharged the next day: her bleeding had stopped, her condition was stable, and her epigastric bruit had disappeared. She made an uncomplicated recovery, and subsequent sigmoidoscopy and rectal biopsy gave normal results.

\section{Comment}

Because of her history of systemic lupus erythematosus we postulate that this patient had had a compromised circulation to the large bowel, which the mechanical effects of colonoscopy reduced to below a critical level. We found no evidence of large vessel disease, but one possibility must be that her small vessel circulation was compromised as a result of her connective tissue disease.

(Accepted 1 August)

\section{Screening for carriers of cystic fibrosis among partners of people heterozygous for the disease}

\section{Felix H Sennhauser, Sabina Liechti-Gallati, Hans Moser}

\section{Ostschweizerisches Kinderspital, CH-9006 St Gallen, Switzerland Felix H Sennhauser, MD, director, paediatric pulmonology}

\section{Universitäts-Kinderklinik,} Inselspital, Bern Switzerland

Sabina Liechti-Gallati, PHD, head, molecular genetics laboratory

Hans Moser, MD, director, clinical genetics service

Correspondence to: Dr Sennhauser.

Br Med f 1990;301:1081
Since the gene for cystic fibrosis was sequenced in $1989^{1}$ there has been much debate on the introduction of screening for carriers in the population. ${ }^{23}$ The most common mutation is the deletion of three base pairs $\left(\Delta F_{508}\right)$ in exon 10 of the transmembrane conductance regulator on cystic fibrosis chromosomes ${ }^{4}$; the 30 or more other mutations identified so far are very rare and thus much less suitable for screening. The frequency of $\Delta F_{508}$ in cystic fibrosis chromosomes varies among different populations and ethnic groups. In Switzerland this deletion is present in about $70 \%$ of cystic fibrosis chromosomes and the prevalence of carriers (q) is about 1 in 20 .

A serious problem with screening for carriers is that it will detect many couples in which only one partner carries $\Delta \mathrm{F}_{508}$, but heterozygosity in the other partner cannot be excluded without screening for the increasing number of other, rare mutations. General screening may be acceptable if the risk of having an affected child is less after screening than before. This means that with a prevalence of carriers of 1 in $20(5 \%)$ population screening should be postponed until at least $96 \%$ of the mutations can be detected. ${ }^{2}$

In high risk circumstances, however, such as marriages between a heterozygous relative of a patient with cystic fibrosis and an unrelated partner screening of both partners for $\Delta \mathrm{F}_{508}$ can help in genetic counselling and prenatal diagnosis. This is shown by the recent results of DNA analysis. in a Swiss family affected by cystic fibrosis.

\section{Subjects, methods, and results}

After his divorce the father of a patient with cystic fibrosis asked about the risk of having another child with cystic fibrosis as he wanted to marry an unrelated Swiss woman with no family history of cystic fibrosis. The risk before screening $(1 / 4 \times q)$ was $1 / 4 \times 1 / 20=1 / 80$.
If the woman was shown not to be a carrier of $\Delta F_{508}$ the risk of having a child with cystic fibrosis $(1 / 4 \times(1-a) \times q)$ would be reduced to $1 / 4 \times 0 \cdot 3 \times 1 / 20=1 / 267$, where $\mathrm{a}$ is the proportion of mutations screened for $(0 \cdot 7$ for $\left.\Delta F_{508}\right)$. The risk after screening would therefore be less than that before. The probability of $\Delta F_{508}$ not occurring in a partner unrelated to $\operatorname{him}((1-\mathrm{q}):(1-\mathrm{aq}))$ was $98 \cdot 4 \%$. Alternatively, if the woman was shown to be a carrier of $\Delta F_{508}$ (probability $1 \cdot 6 \%$ ) the risk of having an affected child would be $1 / 4$, but the reliability of prenatal diagnosis of cystic fibrosis in a future pregnancy would be $100 \%$.

After being told of these theoretical results the couple asked for an analysis of DNA. Unfortunately, this showed that both of them were carriers of $\Delta F_{508}$, and they decided to consider prenatal diagnosis.

\section{Comment}

We suggest that screening for $\Delta F_{508}$ should be offered to partners of people heterozygous for cystic fibrosis in countries in which the prevalence of carriers is about $5 \%$ and the prevalence of the deletion on cystic fibrosis chromosomes is about $70 \%$. Under these circumstances the risk of having a child with cystic fibrosis after screening would be less than that before screening for 49 out of 50 couples.

This study was supported by the Swiss National Science Foundation.

1 Rommens JM, Ianuzzi MC, Kerem B, et al. Identification of the cystic fibrosis gene: chromosome waking and jumping. Science 1989;245:1059-65.

Ten Kate LP. Carrier screening in CF. Nature 1989;342:131.

3 Colten HR. Screening for cystic fibrosis. Public policy and personal choices. $N$ Engl f Med 1990; 322:328-9.

4 Kerem B, Rommens JM, Buchanan JA, et al. Identification of the cystic fibrosis gene: genetic analysis. Science 1989;245:1073-80.

(Accepted 23 August 1990)

\section{Correction}

Cost analysis of prophylaxis with antibiotics to prevent infected knee arthroplasty

Three authors' errors occurred in this paper by Dr Sten Bengtson and colleagues $(1989 ; 299: 719-20)$. In the table the total cost for patients with infection should be $\mathrm{Kr} 358166$ and not 353951 ; in the paragraph before the comment the cost saved with flucloxacillin is $\mathrm{Kr} 136617$ and with cephalexin is $\mathrm{Kr} 119459$ and not the other way round as published; and reference 2 was in fact published in the fournal of Bone and foint Surgery $[\mathrm{Br}]$ $(1984 ; 66: 580-2)$ and not in Clinical Orthopaedics. 